\title{
Medial subtalar dislocation with navicular and posterior talar process fracture: the first report in the literature
}

\author{
Neil Eisenstein, David Hillier, Sarfraz Ahmad
}

Department of Trauma and Orthopaedics, Princess Royal Hospital Telford, Telford, Shropshire, UK

Correspondence to Neil Eisenstein, eisenstein@doctors.org.uk
To cite: Eisenstein $\mathrm{N}$, Hillier D, Ahmad S. BM」 Case Rep Published online: [please include Day Month Year] doi:10.1136/bcr-2012007763

\section{DESCRIPTION}

Subtalar dislocations are rare types of injury and account for approximately $1 \%$ of all dislocations. There is simultaneous disruption of both the talocalcaneal and talonavicular joints, whereas the tibiotalar and calcaneocuboid joints remain undisturbed. Medial subtalar dislocations are the most common (up to $85 \%$ ), with lateral types making up the majority of the rest. ${ }^{1} 2$ Total anterior or posterior dislocations are extremely rare. These injuries may be associated with fractures of the bones of the foot and ankle.

Reviewing the literature reveals no previous reports of posterior talar process and navicular fracture, in the presence of a total medial subtalar dislocation (as in this case). Fotiadis et $\mathrm{al}^{3}$ have reported on a medial subtalar dislocation with nondisplaced fractures of the talar body and navicular (figure 1).

Papers describing total talar dislocation have shown that open reduction is required in most cases.

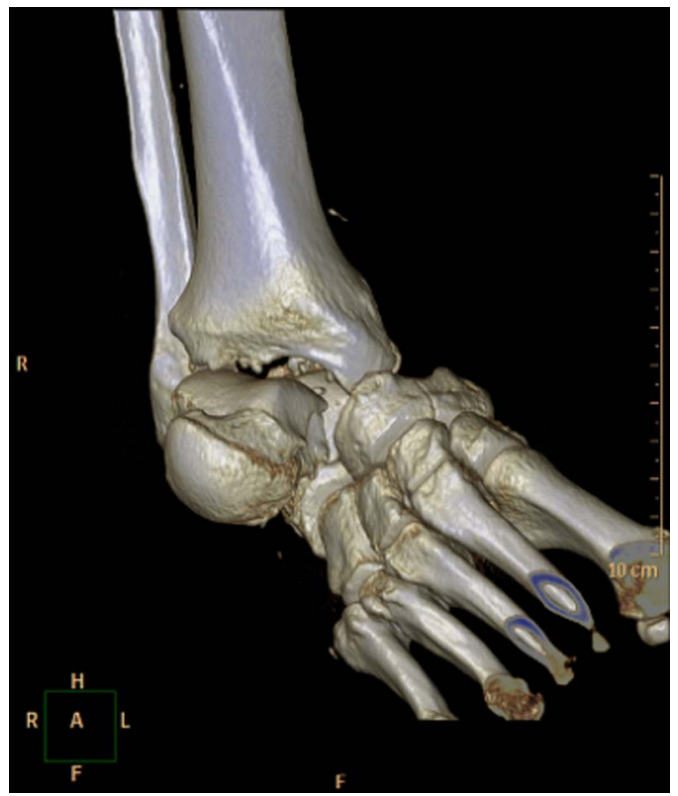

Figure $1 \mathrm{CT}$ reconstruction demonstrating medial subtalar dislocation (posterior talar process and navicular fractures seen on sectional imaging).
This should be undertaken urgently as it reduces deformity and subsequent nerve, blood vessel or skin damage. Talectomy may be required as an interval procedure due to the development of avascular necrosis or osteomyelitis (eg, after open total dislocation). Ankle fusion is also described as a second procedure in cases of complicated total talar dislocation with or without accompanying fracture. Xarchas et al describe a closed method of reduction under general anaesthetic whereby the knee is flexed and the talus is pushed posteromedially.

In this case, closed reduction under general anaesthetic failed. Open reduction was successful and revealed that the talus had 'button-holed' through the dorsal facia preventing closed reduction.

\section{Learning point}

Subtalar dislocations with concomitant fractures are rare injuries. Therefore, the best and most reliable way of treating this significant trauma remains unknown. However, what is clear is that the subtalar dislocation should be reduced, whether by a closed or open method. The management of the associated fracture(s) will depend on many factors, particularly displacement of the fracture fragments.

Contributors All the authors were involved in the clinical care of the patient. All the authors contributed equally in the concept, research, design, writing, reviewing and editing of the manuscript. All authors approved the final draft of the manuscript.

Competing interests None.

Patient consent Obtained.

Provenance and peer review Not commissioned; externally peer reviewed.

\section{REFERENCES}

1 DeLee JD, Curtis R. Subtalar dislocation of the foot. J Bone Joint Surg 1982;64A:433-7.

2 Grantham SA. Medial subtalar dislocation: five cases with a common etiology. J Trauma 1964:4:845-9.

3 Fotiadis E, Lyrtzis C, Svarnas T, et al. Closed subtalar dislocation with non-displaced fractures of talus and navicular: a case report and review of the literature. Cases J 2009;2:8793. 


\section{Images in...}

Copyright 2013 BMJ Publishing Group. All rights reserved. For permission to reuse any of this content visit http://group.bmj.com/group/rights-licensing/permissions.

BMJ Case Report Fellows may re-use this article for personal use and teaching without any further permission.

Become a Fellow of BMJ Case Reports today and you can:

- Submit as many cases as you like

- Enjoy fast sympathetic peer review and rapid publication of accepted articles

- Access all the published articles

- Re-use any of the published material for personal use and teaching without further permission

For information on Institutional Fellowships contact consortiasales@bmjgroup.com

Visit casereports.bmj.com for more articles like this and to become a Fellow 